\title{
The Use of Art Therapy in Conflictology in Education
}

\author{
Baynova Maria ${ }^{1, *}$, Maslikov Vadim², Polyakova Svetlana ${ }^{3}$, Palekhova Polina ${ }^{4}$, Sulyagina Julia1 \\ ${ }^{1}$ Department of management and public administration, Russian State Social University, Moscow, Russia \\ ${ }^{2}$ Research committee on Social Management, Russian Society of Sociologists, Moscow, Russia \\ ${ }^{3}$ Department of art-aesthetic cycle, School 1273, Moscow, Russia \\ ${ }^{4}$ Russian Presidential Academy of National Economy and Public Administration, Russian State Social University, Moscow, Russia
}

Received November 1, 2019; Revised December 24, 2019; Accepted December 30, 2019

Copyright $\bigcirc 2020$ by authors, all rights reserved. Authors agree that this article remains permanently open access under the terms of the Creative Commons Attribution License 4.0 International License

\begin{abstract}
The aim of the article is to evaluate and analyze the possibility of applying art therapy technologies to conflict management in the field of education among teachers of creative disciplines. In the paper, a comprehensive approach to analysis of interpersonal conflicts in a group as well as intrapersonal conflicts of individual team members is offered as a solution to interpersonal tensions reduction and conflict prevention. Authors propose conflictological role-playing game based on the art-therapeutic approach (ATA), which is a theatrical act including conflicts prescribed in the characters and their interaction as a creative training method. The article presents the results of art therapy application as a means of conflict management in pedagogical environment. The scientific novelty of the study is the assessing the results of the using art therapy among teachers of creative disciplines. The data obtained in the research and presented in this article can be employed in conflict consulting in creative oriented groups.
\end{abstract}

Keywords Conflict, Conflict Consulting, Art Therapy, Conflicts in Education, School Teachers

\section{Introduction}

The cause of the interpersonal conflicts in a collective (working team) lies generally in a clash between interpersonal and intrapersonal interests equally. Therefore, attention should be paid not only to the feature of work in the institution but also to the personal characteristics of an employee for conflict resolution. Creativity and interest in personal growth should not be underestimated since an employee in a state of intrapersonal comfort and balance is the best one to achieve conflict-free, and therefore, shows better results working in a team. $[8,9,12]$ Thus, the resolution to an interpersonal conflict within a team is impossible to reach without dealing with all participants.

One of the ways to work out intrapersonal problems and solve interpersonal conflicts is art therapy. This is a comprehensive method for interpersonal conflicts prevention aimed at the correction of communicative, emotional, and cognitive aspects of a personality thus contributing to personal fulfillment. Art therapy is based on the conviction that a creative process and art self-expression is an expedient method of resolving conflict situations and problems, developing communication skills, managing behavior, reducing stress, increasing self-esteem and self-awareness and gaining mutual understanding. The importance of art therapy for conflictology is undoubted since art therapy allows a person to express his or her emotions and fears visually, which is impossible to do in a regular manner; as a result of this, a person gains awareness of his or her ability to control emotions. A team with a high degree of psychological tension, which means greater emotional instability and a tendency to conflict situations, is a promising base for specialized art-therapy training. The method of art therapy is of particular interest in the field of education since the educational process is associated with interpersonal interaction, which leads to high probability of conflicts.

\section{Review on Literature}

Art therapy arose in the middle of XX century as a method of psychotherapeutic practice. Art therapy is considered to be a means of maintaining emotional stability in a team through art activity ( $\mathrm{T}$. Zinkevich-Evstigneeva, [34]). The art therapy may be a tool for assessment of conflict and avenue for therapeutic reduction of conflict at the turn of the XXI century [22, 31]. Ditty Dokter presents a number of studies on in dramatherapy $[11,28]$. The arts-based activities can help for working with conflict in intercultural groups [14]. 
Creative use of visual arts within conflict resolution is a subject of research by E. Huss [16].

B.D. Karvasarsky concludes that art therapy is "a favorable basis for a creative rethinking of one's problems and conflicts, developing deeper and more adequate self-understanding, overcoming unconstructive behavioral stereotypes and ways of emotional response, the formation of new, adequate behavior and new ways of emotional response" [18].

In pedagogy, it is often considered as a tool to overcome conflicts between students and teachers. However, the question remains: whether art therapy can be used within a teaching community to resolve conflicts and improve working climate?

Both N.I. Anufrieva and I.S. Avramkova give credence to the future of art therapy in creative learning [5]. Thus, in one of her studies, L. V. Nozhichkina considers art therapy as one of the ways to overcome the emotional burnout syndrome among teachers. According to the paper, the techniques like making collective drawings were used during refresher teaching training and this led to a deeper understanding of the roots of conflict situations among teachers and helped to learn how to resolve them [27, p. 157]. Moreover, N. N. Kolmogortseva [21] also considers drawing as a part of the art therapy used to correct the emotional state of teachers. A study of applying art therapy for better onboarding of young teachers has been made by L.A. Belozerova and L.V. Gurylyova [7], when M. S.Valdes and A. G. Moskovkina [21] see drama therapy as an effective approach to conflicts solution mainly among students.

The methods of psychodrama and drama therapy are studied by J. Moreno, M. Andersen-Warren, R.Granger. $[26,2]$, and psychodrama potential is reviewed by Leutz [24]. Both drama therapy and psychodrama have been adapted to the principles of art therapy in conflict management and taken as the basis for working out both intrapersonal and interpersonal conflicts. The experience of applying such training for work with teachers in a Moscow school is described in the study of I. G. Kolmakova [20]. Alekseeva describes the possibility of applying this approach to conflict management in education [1]. Conflicts assessment in the creative team is given by Antsupov and Dmitriev [4, 11]. The authors present the results of the first test phase of art therapy application to conflict resolution within the educational sphere [25] and the use of this method in conflict resolution in creative groups in education [6].

In modern international studies, art therapy is widely represented, but the potential of its application within pedagogical groups still has not been investigated thoroughly. Researches of art therapy in educational institutions in the Czech Republic [17] and the direction of art therapy at schools [33] are worth noting. A survey of teachers' self-regulation with the help of art therapy is of great interest. According to the results of the study, using art therapy creates a positive relationship between indicators of external regulation, internal motivation and motivation for success [15]. The survey of results of pedagogical practice of students who study art and art therapy deserves attention; although art-therapeutic methods were not used, the influence of art therapy on their activity and cooperation was summarized [13]. Foreign studies also explore examples of art therapy application to resolve conflicts in a multicultural environment, mainly social ones. For instance, Goldblatt and others support the practical use of the art therapy tool to assess conflict and possible ways to therapeutic conflict reduction [14].

The analysis of the sources shows that too little attention is paid to art therapy in a teaching staff, therefore the study submitted in this paper can be interesting as revealing the potential of art therapy in labor controversies in educational organizations.

\section{Materials and Methods}

Consulting on conflict resolution through art therapy was carried out among art teachers working in a Moscow school. A humanities-oriented school with an in-depth study of English and choreography was chosen for the research. Since 2012 the school has been assessing conflict situations and in this school a conflict expert worked for two years (2015-2016).

In the 2016/2017 academic year in one of the school's section a musical was staged, simultaneously an experiment on art therapy use for interpersonal conflict prevention was carried out. The school authorities registered the positive impact of collective art activity on interpersonal interaction. The results of the preliminary stage showed that "a comprehensive art-therapeutic approach in the prevention of interpersonal conflicts among teachers of art gave positive results and allowed us to establish productive working relationships." [25] After some time, the authors noted that an interpersonal conflict might be revealed within the observed group. The emergence of a new wave of tension made the authors think about the root causes of conflicts in the group. Subsequently they made an assumption that interpersonal and intrapersonal conflicts correlate. [3]

During the following academic year, a research into the possibility of applying theoretical issues and practical techniques to dealing with a specific group and monitoring interpersonal relationships of employees were carried out. From 2017 to 2018, art therapy conduction concurred with the school authorities' desire to involve people in participating in amateur performances, thereby the studies received organizational (that is an opportunity to use an event hall twice a week for two academic hours) and financial assistance (quarterly bonus given to art workers to motivate them). The participants were not aware of the experiment; the goal set by school authorities was just to participate in an amateur performance festival. 
These conditions made it possible to introduce a system of art-therapeutic consulting in conflict management, track the dynamics and receive the results of the experiment.

To study relationships within the group and the roots of conflicts the methodology of K. Thomas was used. The Thomas-Kilmann Conflict Mode Instrument is widely used to assess conflict management styles [30]. The "Intrapersonal Conflict test" by Wolf Lauterbach is designed to study the degree of respondent awareness of psychological mechanisms of their problem and the severity of the intrapersonal conflict. [23] Spielberger-Khanin technique is a method of psychodiagnostics. The American psychologist Charles Spielberger has created the technique to measure anxiety as well as a characterization of personality. Yuri Khanin has adapted this method for Russian language and realities. The Spielberger-Khanin method consists of a questionnaire, which items are focused on situational and personal anxiety. The Spielberger-Khanin test can diagnose the level of anxiety in organization in a specific period of time and shows the results of art therapy. [19] "Modular method for interpersonal conflicts testing" by A.Ya Antsupov helps to evaluate and identify interpersonal conflicts inside of groups [3]. This test shows the attitude to each member of the group of all parties to the conflict and the opinion of each member of the group on how his colleagues relate to him, the quality of job made and maturity of moral principles. All these techniques allow us to evaluate the results of applying the art therapy method during the study period.

\section{Results}

A conflictological role-playing game based on the art therapy approach (ATP) is a specially created piece, which includes episodes with all the indicated intrapersonal and interpersonal conflicts. Each separate role is multifunctional and represents a combination of scenes aiming at working out anxiety, stress, interpersonal (by reference to A.Ya. Antsupov) and intrapersonal conflicts emerging in pursuit of satisfying one's own needs, a combination of requirements for various roles as well as an individual part in terms of the level of claims, seeing that the level of claims reflects the internal structure of personality of a participant in role-playing game based on the ATP (art therapy practice). An anonymous questionnaire was composed to determine personal claims of the partakers. Each particular role in the performance was composed basing on the answers. The poll implied anonymity; however, each person was identified by his or her handwriting. In this case, there was neither contradiction with ethical principles nor any violation of the inviolability of personal data. A mediator-conflictologist does not publicly disclose his or her role in the play to obtain a more reliable and positive effect of the training. Since a mediator is not known by the others, he or she submits the proposed questionnaire along with other participants in the conflict resolution role play based on the ATP. [34].

It was decided to use a story from ancient Greek mythology as a basis. Due to a large number of tasks to be solved, all roles were equal. To act out family relationships in the small group a love narrative was presented. The topic of self-realization and satisfaction of one's own needs was acted out by the patterns of divine essence and superpowers. The performance included humorous episodes, with the help of which the level of anxiety and stress was regulated. An individual line was also featured, which reflected the level of claims of each participant in a conflict resolution role play based on ATP.

The motivation to stage the piece was an opportunity to take part in the amateur art contest. Rehearsals were held in a friendly atmosphere, despite interpersonal differences and conflicts. At the first stage, the work consisted of discussing the inner world of main characters, their goals, and function in the storyline of the play, interaction with other heroes. The main task was to get used to the role that is, embedding the character in the player's personality. The work with each participant went on individually.

In the second stage, the researchers concentrated on the interpersonal interaction of the participants during the performance. Special focus was on small conflict groups (e.g. dyads, triads).

At the final stage, the entire script was assembled and the play was released. Precisely at this stage costumes, sets, props appeared. Due to the lack of fund nearly all props and costumes were made manually, which may be seen as an auxiliary tool for the training. Props making and costumes sewing acted as stress relief due to the inclusion of fine motor skills, the creation of decorations works as color therapy, etc.

Table1. The results of the diagnostic phase according to The State-Trait Anxiety Inventory (STAI) by Charles Spielberger - Y. L. Khanina

\begin{tabular}{|c|c|c|}
\hline $\begin{array}{c}\text { Female } \\
\text { respondents }\end{array}$ & $\begin{array}{c}\text { Personal Anxiety } \\
\text { Scale }\end{array}$ & $\begin{array}{c}\text { Situational Anxiety } \\
\text { Scale }\end{array}$ \\
\hline Choreographer 1 & 59 points & 54 points \\
\hline Choreographer 2 & 49 points & 62 points \\
\hline Choreographer 3 & 63 points & 49 points \\
\hline Concertmaster 1 & 43 points & 51 points \\
\hline Vocal teacher 1 & 56 points & 50 points \\
\hline Male respondents & $\begin{array}{c}\text { Personal Anxiety } \\
\text { Scale }\end{array}$ & $\begin{array}{c}\text { Situational Anxiety } \\
\text { Scale }\end{array}$ \\
\hline Choreographer 4 & 50 points & 46 points \\
\hline Concertmaster 2 & 40 points & 45 points \\
\hline Acting teacher 1 & 63 points & 55 points \\
\hline Acting teacher 2 & 45 points & 39 points \\
\hline Vocal teacher 2 & 40 points & 38 points \\
\hline
\end{tabular}

To evaluate the results of the use of art therapy the experimental group was tested: at the preparatory (diagnostic) stage at the end of September 2017 and at the final stage at the end of May 2018. All tests and surveys were conducted anonymously. Among the interviewed 
teachers of art, there are five male and five female persons, who took part in amateur performances throughout the school year.

The test for the emotional state (level of anxiety) of the participants during the experiment was carried out basing on the test by Ch. Spielberger. A summary table of the results of the diagnostic phase is presented in table 1 .

In the course of processing the results, the hypothesis of the presence of intrapersonal conflicts between the participants in the experimental group was confirmed. An overestimated or extreme level of personal and situational anxiety (50 points or more) indicates the presence of internal contradictions.

At the final stage, the results of this testing are as follows (presented below in Table 2).

The diagnostic tables of the initial and final stages show positive dynamics. The level of personal anxiety decreased markedly while the scale of situational anxiety leveled off.

Taking it into consideration, we faced the need for a more detailed examination of the intrapersonal state of the group members; for this, the method of "Intrapersonal Conflict test" by Wolf Lauterbach was used.

The participants (five male and five female art teachers) were offered fourteen statements to be assessed on a true-false scale following the respondent's current life situation. A summary table of the results of the diagnostic phase is presented in Table 3.

The obtained results confirmed the hypothesis proposed: more than half of the respondents had a rather high level of intrapersonal disharmony. We also note that both male and female respondents refused to answer some points at all, explaining this by the too personal matter of questions, which also indicates emotional distress. According to the results of the testing during the final stage, the level of trust and openness changed.

Table 2. The results of the final stage according to The State-Trait Anxiety Inventory (STAI) by Charles Spielberger - Y. L. Khanina

\begin{tabular}{|c|c|c|}
\hline $\begin{array}{c}\text { Female } \\
\text { respondents }\end{array}$ & $\begin{array}{c}\text { Personal Anxiety } \\
\text { Scale }\end{array}$ & $\begin{array}{c}\text { Situational Anxiety } \\
\text { Scale }\end{array}$ \\
\hline Choreographer1 & 51 points & 45 points \\
\hline Choreographer 2 & 38 points & 41 points \\
\hline Choreographer 3 & 41 points & 39 points \\
\hline Concertmaster 1 & 43 points & 42 points \\
\hline Vocal teacher 1 & 50 points & 46 points \\
\hline Male respondents & $\begin{array}{c}\text { Personal Anxiety } \\
\text { Scale }\end{array}$ & $\begin{array}{c}\text { Situational Anxiety } \\
\text { Scale }\end{array}$ \\
\hline Choreographer 4 & 50 points & 39 points \\
\hline Concertmaster 2 & 40 points & 38 points \\
\hline Acting teacher 1 & 63 points & 48 points \\
\hline Acting teacher 2 & 45 points & 33 points \\
\hline Vocal teacher 2 & 40 points & 34 points \\
\hline
\end{tabular}

To diagnose a strategy for behavior in conflict, $\mathrm{K}$. Thomas "Conflict behavior strategies" technique was used. [30] In the course of processing the results, it turned out that only two participants in the experimental group adhere to the most productive strategy of behavior in conflict (cooperation). Three respondents adhere to the rivalry strategies, two of them chose adaptations, one preferred a compromise and two chose avoidance. The results of the diagnostic stage are presented in Table 4.

Table3. The results of the diagnostic stage of testing by the method of "Intrapersonal conflicts test" by V. Lauterbach

\begin{tabular}{|c|c|c|c|c|c|}
\hline Female respondents & Absolutely true & Rather true & Partially true, partially incorrect & Rather, incorrectly & The sum of the points \\
\hline Choreographer1 & 24 points & 12 points & 6 points & 1 points & 43 points \\
\hline Choreographer 2 & 32 points & 15 points & 2 points & 0 points & 49 points \\
\hline Choreographer 3 & 20 points & 12 points & 6 points & 1 points & 39 points \\
\hline Concertmaster 1 & 24 points & 12 points & 4 points & 1 points & 42 points \\
\hline Vocal teacher 1 & 28 points & 15 points & 2 points & 46 points \\
\hline Male respondents & Absolutely true & Rather true & Partially true, partially incorrect & Rather, incorrectly & The sum of the points \\
\hline Choreographer 4 & 40 points & 6 points & 4 points & 0 points & 50 points \\
\hline Concertmaster 2 & 24 points & 15 points & 6 points & 1 points & 45 points \\
\hline Acting teacher 1 & 32 points & 12 points & 2 points & 1 points & 46 points \\
\hline Acting teacher 2 & 28 points & 12 points & 4 points & 1 points & 42 points \\
\hline Vocal teacher 2 & 24 points & 15 points & 2 points & & \\
\hline
\end{tabular}


Table 4. The results of the diagnostic phase of testing according to K. Thomas' "Conflict behavior strategies" technique

\begin{tabular}{|c|c|c|c|c|c|}
\hline Respondents & Competition & Adaptation & Compromise & Avoidance & Cooperation \\
\hline Choreographer1 & $*$ & & & & \\
\hline Choreographer 2 & & $*$ & & & \\
\hline Choreographer 3 & $*$ & & & & \\
\hline Choreographer 4 & $*$ & & & & $*$ \\
\hline Concertmaster 1 & $*$ & & & & $*$ \\
\hline Concertmaster 2 & & & & & \\
\hline Acting teacher 1 & & & & & \\
\hline Acting teacher 2 & & & & & \\
\hline Vocal teacher 1 & & $*$ & & & $*$ \\
\hline Vocal teacher 2 & & & & & \\
\hline
\end{tabular}

At the final stage during testing according to the following method (by K. Thomas), a positive shift becomes noticeable. Only one choreographer 4 chose a rivalry strategy, five members of a group chose cooperation, three - a compromise, two - adaptation, no one chose avoidance. The results of the final stage are presented in Table 5.

Table 5. The results of the final stage of testing according to the method of K. Thomas' "Conflict behavior strategies" technique

\begin{tabular}{|c|c|c|c|c|c|}
\hline Respondents & Competition & Cooperation & Adaptation & Compromise & Avoidance \\
\hline Choreographer1 & & & $*$ & & \\
\hline Choreographer 2 & & $*$ & & & \\
\hline Choreographer 3 & & $*$ & & & \\
\hline Choreographer 4 & $*$ & & & & \\
\hline Concertmaster 1 & & $*$ & & & \\
\hline Concertmaster 2 & & & & $*$ & \\
\hline Acting teacher 1 & & & $*$ & & \\
\hline Acting teacher 2 & & & & $*$ & \\
\hline Vocal teacher 1 & & & $*$ & & \\
\hline Vocal teacher 2 & & $*$ & & & \\
\hline
\end{tabular}

The "Modular method for interpersonal conflicts testing" by A.Ya. Antsupova, A.I. Shipilova was used for more detailed interpersonal conflicts testing in a group (which implies the attitude of all group members towards each member separately and group members' attitude to themselves), [3] the results of the diagnostic stage are presented in Table 6 .

Table 6. The results of the diagnostic phase of testing according to the methodology "Conflict behavior strategies".

\begin{tabular}{|c|c|c|c|c|c|}
\hline Respondents & $\begin{array}{c}\text { Relationship to } \\
\text { colleagues }\end{array}$ & $\begin{array}{c}\text { Relationship to } \\
\text { myself }\end{array}$ & $\begin{array}{l}\text { Professional } \\
\text { knowledge }\end{array}$ & Quality of working & $\begin{array}{c}\text { Importance of } \\
\text { Interest }\end{array}$ \\
\hline Choreographer1 & neutral & neutral & hard to rate & average level & $\begin{array}{c}\text { Individual } \\
\text { interests }\end{array}$ \\
\hline Choreographer 2 & hard to rate & hard to rate & average level & average level & $\begin{array}{c}\text { Individual } \\
\text { interests }\end{array}$ \\
\hline Choreographer 3 & hard to rate & neutral & average level & $\begin{array}{c}\text { more negative than } \\
\text { positive }\end{array}$ & individual interests \\
\hline Choreographer 4 & negative & hard to rate & above-average & $\begin{array}{c}\text { more negative than } \\
\text { positive }\end{array}$ & individual interests \\
\hline Concertmaster 1 & neutral & neutral & average level & average level & individual interests \\
\hline Concertmaster 2 & neutral & hard to rate & above-average & average level & individual interests \\
\hline Acting teacher 1 & neutral & positive & above-average & average level & collective interests \\
\hline Acting teacher 2 & hard to rate & hard to rate & average level & average level & individual interests \\
\hline Vocal teacher 1 & negative & hard to rate & above-average & $\begin{array}{l}\text { more negative than } \\
\text { positive }\end{array}$ & individual interests \\
\hline Vocal teacher 2 & hard to rate & neutral & average level & average level & individual interests \\
\hline
\end{tabular}


Table 7. The results of the final stage of testing according to the methodology "Conflict behavior strategies".

\begin{tabular}{|c|c|c|c|c|c|}
\hline Respondents & $\begin{array}{c}\text { Relationship to } \\
\text { colleagues }\end{array}$ & $\begin{array}{c}\text { Relationship to } \\
\text { myself }\end{array}$ & $\begin{array}{c}\text { Professional } \\
\text { knowledge }\end{array}$ & $\begin{array}{c}\text { Quality of } \\
\text { working }\end{array}$ & $\begin{array}{c}\text { Importance of } \\
\text { Interest }\end{array}$ \\
\hline Choreographer1 & positive & positive & above-average & high & Individual interests \\
\hline $\begin{array}{c}\text { Choreographer } \\
2\end{array}$ & neutral & neutral & above-average & above-average & Individual interests \\
\hline $\begin{array}{c}\text { Choreographer } \\
3\end{array}$ & neutral & positive & high & high & individual interests \\
\hline $\begin{array}{c}\text { Choreographer } \\
4\end{array}$ & hard to rate & hard to rate & above-average & average level & individual interests \\
\hline Concertmaster 1 & positive & neutral & above-average & above-average & individual interests \\
\hline Concertmaster 2 & neutral & neutral & high & average level & individual interests \\
\hline Acting teacher 1 & positive & positive & high & high & collective interests \\
\hline Acting teacher 2 & neutral & neutral & above-average & above-average & individual interests \\
\hline Vocal teacher 1 & hard to rate & neutral & high & above-average & individual interests \\
\hline Vocal teacher 2 & hard to rate & positive & high & above-average & individual interests \\
\hline
\end{tabular}

At the final stage, in the diagnostic process based on this technique, the attitude towards colleagues in most of the experimental group was aligned with positive dynamics (four rated the ratio with a positive parameter, four - with a neutral one, two - with difficulty). Participants' attitudes towards themselves also changed: four - positive, five - neutral, one considered it difficult to evaluate. The results of the final stage are presented in Table 7.

\section{Conclusions}

The study confirms the hypothesis of synergy between intrapersonal and interpersonal conflicts. The goal of the experiment was achieved, that is the observed indicators of conflict in creative groups were optimized and the atmosphere comfortable for creative activity was produced. It was concluded that repeated tests confirmed empirical observations. Conflict indicators decreased by 1.5-2.0 times and internal self-regulation and self-control was built up within the group. The general background mood improved and became more positive.

It should also be noted that some participants in the role -playing game acquired hobbies related to art therapy such as knitting, embroidery, felting, painting in various techniques. Some of the participants started to attend continuing education courses in their core profession. Thus, their status in the group rose; accordingly, their colleagues' attitude altered and relationship in the group improved, which led to decline in interpersonal conflicts.

The method of art therapy proved to be an appropriate measure to settle conflicts and resolve discrepancy between the level of claims and the level of achievement as well as to alleviate the conflict between a desire and the possible like inability to combine the requirements of different roles.

However, the potential of theater performance as an art-therapeutic and therapeutic phenomenon has not been thoroughly explored yet. This is an opportunity for research not only to people in creative professions but also in other areas - doctors, psychologists, sociologists, teachers. Interest in the theater suggests the involvement in the game, which means an opportunity to live a number of interesting lives and develop scenarios for a short period of time. This is a good chance to feel what it is like to be another person. Science is feasible to study and make the most of this phenomenon in order to harmonize life and accordingly, prevent conflicts.

Research in this area is far from complete. The authors plan to organize the introduction of role-playing among non-creative groups. Such implementation will require the mediator to rethink the sociocultural environment, psychological atmosphere, principles of organizing the life of such organizations, which will require expansion, and perhaps the creation of a new approach to the idea of training. This is a matter of future research.

\section{REFERENCES}

[1] Alekseeva M. Yu. Practical application of elements of art therapy in the teacher's work, Moscow, 2013.

[2] Andersen-Warren M., Granger R. Practical approaches to drama therapy, London, 2000.

[3] Antsupov A. J., Shipilov A. I. Conflict management: Textbook for universities, St. Petersburg, Peter, 2008.

[4] Antsupov A. Ya., Baklanovskiy S. V. Conflict in the diagrams and comments, St. Petersburg, Peter, 2009.

[5] Anufrieva N.I., Avramkova I.S. New educational technologies and their prospects in music pedagogy, Scientific notes of the Russian State Social University, 2018, Vo. 17, N. 2 (147), 103-111. 
[6] Baynova, M. S., Vetrova, E. A., Kabanova, E. E., Palehova, P. V., \& Petrov, A. V. Extracurricular work in modern vocational education under the programs of development, socialization and students' health preservation. Perspectives of Science and Education, 2019, V. 41, No. 5, 86-97. doi: 10.32744/pse.2019.5.7

[7] Belozerova L.A., Guryleva L.V. Art therapy as a health-saving technology, accompanied by socio-psychological adaptation of young teachers, Pedagogical-psychological and biomedical problems of physical education and sport, 2018, Vol. 13, No. 4., 101-108.

[8] Berne, E. Principles of Group Treatment, Oxford University Press, 1966

[9] Berne E. Games People Play, NY, Grove Press, 1996.

[10] Dmitriev A.V. Social conflict: General and special, Moscow, Gardariki, 2007.

[11] Dokter, D. Embodiment in dramatherapy. Routledge International Handbook of dramatherapy, 2016, 115-124.

[12] Egides A. P. Psychology of conflicts in business communication (Concepts and technologies), St. Petersburg, SPbGU, 2006.

[13] Feen-Calligan H. Matthews W. K. Pre-Professional Arts Based Service-Learning in Music Education and Art Therapy. International journal of education and the arts. Vol. 17. No. 17. 2016

[14] Goldblatt R. Elkis-Abuhoff D. Gaydos M. Rose S. Casey S. Unlocking conflict through creative expression. Arts in psychotherapy. 2010. Vol. 38. No. 2. Pp. 104-108.

[15] Hubina S. Teaching activities self-regulation by means of art therapy. Science and education. 2017. Vol. 11. Pp. 114-119. DOI: 10.24195/2414-4665-2017-11-15

[16] Huss E. Creative Use of Visual Arts within Conflict Resolution. The International Journal of Creativity and Problem Solving, 2016, V. 26, No. 1.http://www.creativity.or.kr/page/archive/archive_view.ht ml?report_no $=246$

[17] Kantor J. Chráska M. Ludíková L. Czech Arts Therapies in Educational Institutions. Education science. 2019, 9, 82 DOI: $10.3390 /$ educsci9020082

[18] Karvasarsky B. D., Psychotherapy. A textbook for medical students, St. Petersburg, Peter, 2002.

[19] Khanin Yu.L. A quick guide to using the reactive and personal anxiety scale Spielberger. - Leningrad: LNIITEK, 1976.

[20] Kolmakova I.G. Teaching staff: intelligence and professionalism, The intelligention, its civic position in the modern world, Materials of the XI International Scientific Conference: in 2 volumes, 2016, 215-220.

[21] Kolmogortseva N. N. Art therapy in work with the teaching staff, Bulletin of the Shadrinsk State Pedagogical Institute, 2014, No. 2 (22), 81-86.

[22] Komarenko, V. L. Art-technology in training specialists in helping professions, St. Petersburg, Speech, 2015.
[23] Lauterbach, W. (1975). Assessing psychological conflict. The British Journal of Social and Clinical Psychology, 14(1), 43-47.

[24] Leutz, G. A. Psychodrama: Theorie und Praxis, Berlin, Springer, 2013.

[25] Maslikov V.A., Polyakova S., Sulyagina Yu.O. Art therapy as an innovative method of conflict resolution in creative groups. Economic and Social Development Book of Proceedings, Varazdin Development and Entrepreneurship Agency; Russian State Social University, 2017, 758-767.

[26] Moreno, J. L. Psychodrama, Vol. I, New York, Beacon House, 1946

[27] Nozhichkina L.V. The syndrome of emotional burnout of teachers - as a source of conflict in the educational environment, Conflictology, 2014, No. 1, 149-164.

[28] Penzes, I. van Hooren, S. Dokter, D. Smeijsters, H. Hutschemaekers, G. Material interaction in art therapy assessment. Arts in psychotherapy. 2014, V. 41, No. 5, 484-492. DOI: 10.1016/j.aip.2014.08.003.

[29] Speiser, V. Speiser, P. An arts approach to working with conflict. Journal of humanistic psychology, V. 47, No. 3, 361-366.

[30] Thomas, K.W. and Kilmann, R.H. (1974). Conflict Mode Instrument, Sterling Forest, New York

[31] Vachkov I. V. Art therapy. Development of self-knowledge through a psychological fairy tale, Moscow, 2011.

[32] Valdes M.S., Moskovkina A.G. Art therapy as a method of overcoming emotional stress, Science and school, 2016, No. 2, 133-137.

[33] Wengrower H. Arts therapies in educational settings: An intercultural encounter. The Arts in Psychotherapy 28(2):109-115. DOI: 10.1016/S0197-4556(00)00091-5

[34] Zinkevich-Evstigneeva T. D, Grabenko T. M. Workshop on creative therapy, Moscow, Sfera, 2013. 